\title{
Rapid mineralization of biogenic volatile organic compounds in temperate and Arctic soils
}

\author{
Christian Nyrop Albers ${ }^{1,2}$, Magnus Kramshøj ${ }^{1,2,3}$, and Riikka Rinnan ${ }^{2,3}$ \\ ${ }^{1}$ Department of Geochemistry, Geological Survey of Denmark and Greenland (GEUS), Øster Voldgade 10, \\ 1350 Copenhagen K, Denmark \\ ${ }^{2}$ Department of Geosciences and Natural Resource Management, Center for Permafrost (CENPERM), \\ University of Copenhagen, Øster Voldgade 10, 1350 Copenhagen K, Denmark \\ ${ }^{3}$ Department of Biology, University of Copenhagen, Universitetsparken 15, 2100 Copenhagen E, Denmark
}

Correspondence: Christian Nyrop Albers (cal@geus.dk)

Received: 17 January 2018 - Discussion started: 7 February 2018

Revised: 23 May 2018 - Accepted: 28 May 2018 - Published: 15 June 2018

\begin{abstract}
Biogenic volatile organic compounds (BVOCs) are produced by all life forms. Their release into the atmosphere is important with regards to a number of climaterelated physical and chemical processes and great effort has been put into determining sources and sinks of these compounds in recent years. Soil microbes have been suggested as a possible sink for BVOCs in the atmosphere; however, experimental evidence for this sink is scarce despite its potentially high importance to both carbon cycling and atmospheric concentrations of these gases. We therefore conducted a study with a number of commonly occurring BVOCs labelled with ${ }^{14} \mathrm{C}$ and modified existing methods to study the mineralization of these compounds to ${ }^{14} \mathrm{CO}_{2}$ in four different topsoils. Five of the six BVOCs were rapidly mineralized by microbes in all soils. However, great differences were observed with regards to the speed of mineralization, extent of mineralization and variation between soil types. Methanol, benzaldehyde, acetophenone and the oxygenated monoterpene geraniol were mineralized within hours in all soils. The hydrocarbon monoterpene $p$-cymene was mineralized rapidly in soil from a coniferous forest but was mineralized slower in soil from an adjacent beech stand, while chloroform was mineralized slowly in all soils. From our study it is clear that soil microbes are able to completely degrade BVOCs released by above-ground vegetation as well as BVOCs released by soil microbes and plant roots. In addition to the possible atmospheric implications of this degradation, the very fast mineralization rates are likely important in shaping the net BVOC emissions from soil and it is possible
\end{abstract}

that BVOC formation and degradation may be important but little-recognized parts of internal carbon cycling in soil.

\section{Introduction}

Non-methane biogenic volatile organic compounds (BVOCs) are produced by all life forms, with plants being the most important contributors to the atmospheric concentrations of BVOCs and also the most studied group of BVOC emitters (Laothawornkitkul et al., 2009; Peñuelas et al., 2014). The production of BVOCs in soil (McNeal and Herbert, 2009; Ramirez et al., 2010) and by isolated soil microorganisms (Insam and Seewald, 2010; Garbeva et al., 2014) has been shown as well.

BVOCs have a very high diversity concerning molecular size and chemical structures, which leads to high compoundto-compound variation in lifetimes and reactions in the environment. Chemical oxidation reactions are regarded to be the dominant BVOC sink in air, with impacts on the concentrations of methane, ozone, formation of secondary organic aerosols and consequently on cloud formation (Peñuelas and Staudt, 2010; Glasius and Goldstein, 2016). In addition to chemical reactions in the atmosphere, uptake or deposition of BVOCs into or onto soil has been observed (Ramirez et al., 2010; Spielmann et al., 2017) and so has a bidirectional atmosphere-soil exchange of certain BVOCs (Asensio et al., 2007, 2008; Gray et al., 2014). The mechanism behind the soil uptake has not been investigated, but processes like ad- 
sorption to organic matter, dissolution in soil water and microbial degradation may all be important. Adsorption and dissolution may be predicted if the chemical characteristics of the BVOCs in question are known. The microbial degradability of BVOCs - and especially the rate of degradation are on the other hand very difficult to predict, since degradation rates in soil vary a lot from compound to compound and from soil to soil.

It is known from lab experiments that many BVOCs can be degraded by soil bacteria functioning as substrates for growth (e.g. Cripps, 1975; Misra et al., 1996; Kleinheinz, 1999; El Khawand et al., 2016). However, studies on BVOC degradation in soil or by isolated soil microorganisms have typically used BVOC concentrations of 3-6 orders of magnitude higher than those present in the environment. Degradation experiments with such high concentrations are very well suited for selectively enriching BVOC degraders and showing the potential for use of a degrader organism in industrial processes. However, they do not serve to assess degradation at realistic environmental concentrations, which would be too low to sustain bacterial growth singly due to degradation of a specific BVOC. Thus, we do not know if microbial BVOC degradation in soil is of environmental importance. An exception to this is isoprene degradation, of which there is substantial evidence from laboratory experiments with different temperate forest soils conducted at isoprene concentrations close to what may be found in the environment (Cleveland and Yavitt, 1997; Gray et al., 2015).

Degradation experiments with BVOCs in soil are difficult to interpret as the same compounds may be produced and released by the soil while also being degraded. By using isotopically labelled compounds in degradation experiments it is possible to target degradation alone. Isotopic labelling also enables working with compounds at lower concentrations. This is especially true for using radioactive ${ }^{14} \mathrm{C}$ labelling, which furthermore enables one to determine complete mineralization to ${ }^{14} \mathrm{CO}_{2}$. Compared to compound removal over time, complete mineralization leaves no doubt that degradation is occurring and is often used in pesticide fate studies. However, apart from three studies looking at mineralization of ${ }^{14} \mathrm{C}$-labelled geraniol (Owen et al., 2007), methanol (Stacheter et al., 2013) and chloroform (Albers et al., 2011), we are unaware of such studies with BVOCs. Furthermore, so far no BVOC mineralization studies were done at concentrations observed in natural environments.

The aim of this study was to assess microbial mineralization of different BVOCs in soils from contrasting environments. The microbial sink of BVOCs in soil would be of potentially high importance to both carbon cycling and atmospheric concentrations of these gases. We therefore purchased a number of commonly occurring BVOCs labelled with ${ }^{14} \mathrm{C}$ and modified existing methods to study the mineralization of these compounds to ${ }^{14} \mathrm{CO}_{2}$ in four different soils.

\section{Materials and methods}

\subsection{Soil sampling and characterization}

Soil was sampled at four sites representing common ecosystem types in the temperate and Arctic temperature zones. From the temperate zone, we sampled a coniferous forest site $\left(56^{\circ} 02^{\prime} 22^{\prime \prime} \mathrm{N}, 12^{\circ} 03^{\prime} 40^{\prime \prime} \mathrm{E}\right)$ dominated by Norway spruce (Picea abies) and Scots pine (Pinus sylvestris) and a European beech (Fagus sylvatica) forest site $\left(56^{\circ} 02^{\prime} 22^{\prime \prime} \mathrm{N}\right.$, $12^{\circ} 04^{\prime} 22^{\prime \prime} \mathrm{E}$ ). The two sites were located $750 \mathrm{~m}$ apart. At both sites the Aeolian sandy soil is 200 to 400 years old and has been forested for at least 150 years. Both sites lack underwood, forest floor vegetation and moss cover, and a $5-10 \mathrm{~cm}$ thick organic layer has accumulated on top of the sand. Loose litter was removed before sampling the organic layer. From the Arctic, we sampled a tundra heath site $\left(69^{\circ} 15^{\prime} 49^{\prime \prime} \mathrm{N}\right.$, $53^{\circ} 27^{\prime} 48^{\prime \prime} \mathrm{W}$ ) dominated by $5-15 \mathrm{~cm}$ tall dwarf shrubs Empetrum nigrum, Betula nana and Cassiope tetragona. A 4$8 \mathrm{~cm}$ thick organic layer accumulated on top of a sandy parent soil. We sampled the organic layer between individual plants. The second Arctic site was an area with bare ground without vegetation and with coarse soil particles (bare Arctic soil; $69^{\circ} 15^{\prime} 57^{\prime \prime} \mathrm{N}, 53^{\circ} 27^{\prime} 58^{\prime \prime} \mathrm{W}$ ), located $300 \mathrm{~m}$ from the heath site. Here, the top $5 \mathrm{~cm}$ was sampled. The location of the Arctic and temperate sites is shown on a map in Fig. S1 in the Supplement.

From each site, 10-12 replicate samples were cored with a brass core (diameter $38 \mathrm{~mm}$ ) from within a $25 \mathrm{~m}^{2}$ area and pooled in a plastic bag. After arrival to the laboratory, the pooled samples were gently mixed by hand and larger roots were removed to get the final soil sample. The bare Arctic soil contained no roots and instead of being mixed by hand, this soil was homogenized by sieving $(5 \mathrm{~mm})$. The mixed samples were stored at $3{ }^{\circ} \mathrm{C}$ for a period of up to 6 weeks before mineralization experiments were initiated.

Water content was determined gravimetrically after drying at $105^{\circ} \mathrm{C}$ for $24 \mathrm{~h}$. Soil organic matter was determined as loss on ignition (LOI; $550^{\circ} \mathrm{C}, 2 \mathrm{~h}$ ). $\mathrm{pH}$ was determined with a pH electrode in slurries of soil : water $(1: 2.5)$ after $30 \mathrm{~min}$ of shaking.

For each soil, triplicate DNA extractions were made from $0.25 \mathrm{~g}$ subsamples using the PowerLyzer PowerSoil DNA Isolation Kit (MoBio, Carlsbad, California). Total bacterial biomass was quantified as $16 \mathrm{~s}$ gene copies by qPCR targeting the $16 \mathrm{~S}$ rRNA sequence using a forward primer $341 \mathrm{~F}\left(5^{\prime}\right.$ CCTACGGGAGGCAGCAG-3') and reverse primer 518R (5'-ATTACCGCGGCTGCTGG-3') and a $1 \mu \mathrm{L}$ DNA template, as previously described (Feld et al., 2016). Total fungal biomass was determined as ITS2 gene copies by targeting the fungal ITS2 nuclear ribosomal DNA region using forward primer gITS7 (GTGARTCATCGARTCTTTG) and reverse primer ITS4 (TCCTCCGCTTATTGATATGC) as previously described (Christiansen et al., 2017). All qPCR were run in technical triplicates. 
Table 1. Characteristics of the model compounds sorted by boiling point (BP). $S_{\mathrm{W}}$ is water solubility. $\infty$ means unlimited solubility (miscible). $X$ means clear evidence for a specified source in the environment. X means that some evidence exists. CAS no. is the chemical abstract service number.

\begin{tabular}{llrrrrrr}
\hline Name & CAS no. & $\begin{array}{r}\mathrm{BP} \\
\left({ }^{\circ} \mathrm{C}\right)\end{array}$ & $\begin{array}{r}\text { Molecular } \\
\text { weight }\end{array}$ & $\begin{array}{r}S_{\mathrm{W}} \\
\left(\mathrm{mg} \mathrm{L}^{-1}\right)\end{array}$ & $\begin{array}{l}\text { Plant } \\
\text { source }\end{array}$ & $\begin{array}{l}\text { Soil/ } \\
\text { microbial } \\
\text { source }\end{array}$ & $\begin{array}{c}\text { Anthropo- } \\
\text { genic } \\
\text { source }\end{array}$ \\
\hline Chloroform & $67-66-3$ & 61 & 119 & 8000 & $(X)^{k}$ & $X^{i, j}$ & $\mathrm{X}$ \\
Methanol & $67-56-1$ & 65 & 32 & $\infty$ & $X^{\mathrm{f}}$ & $X^{\mathrm{a}, \mathrm{b}, \mathrm{e}}$ & $\mathrm{X}$ \\
$p$-cymene & $99-87-6$ & 177 & 134 & 23 & $X^{\mathrm{g}, \mathrm{m}}$ & $(X)^{\mathrm{a}, *}$ & \\
Benzaldehyde & $100-52-7$ & 178 & 106 & 3000 & $X^{\mathrm{f}, \mathrm{m}}$ & $X^{\mathrm{c}, \mathrm{d}}$ & $\mathrm{X}$ \\
Acetophenone & $98-86-2$ & 202 & 120 & 5500 & $X^{\mathrm{m}}$ & $X^{\mathrm{c}, \mathrm{d}}$ & $\mathrm{X}$ \\
Geraniol & $106-24-1$ & 230 & 154 & 686 & $X^{\mathrm{f}, \mathrm{h}}$ & $(X)^{1, *}$ & \\
\hline
\end{tabular}

a Asensio et al. (2007). ${ }^{\mathrm{b}}$ Schink and Zeikus (1980). ${ }^{\mathrm{c}}$ Gutiérrez-Luna et al. (2010). ${ }^{\mathrm{d}}$ McNeal and Herbert (2009). ${ }^{\mathrm{e}}$ Bäck et al. (2010). ${ }^{\mathrm{f}}$ Kesselmeier and Staudt (1999). ${ }^{\mathrm{g}}$ Ortega et al. (2008). ${ }^{\mathrm{h}}$ Chen and Viljoen (2010). ${ }^{\mathrm{i}}$ Hoekstra et al. (1998). ${ }^{\mathrm{j}}$ Albers et al. (2010). ${ }^{\mathrm{k}}$ Laturnus and Matucha (2008). ${ }^{1}$ Schulz and Dickschat (2007). ${ }^{\mathrm{m}}$ Jardine et al. (2010). ${ }^{*}$ Limited evidence of a soil or microbial source of these two monoterpenoids, but clear evidence of general monoterpenoid production in soil and by various microorganisms (e.g. Schulz and Dickschat, 2007; Leff and Fierer, 2008; McNeal and Herbert, 2009; Bäck et al., 2010).<smiles>Cl[C](Cl)Cl</smiles>

$\left[{ }^{14} \mathrm{C}\right]$-Chloroform<smiles>Cc1ccc(C(C)C)cc1</smiles>

[1-methyl- $\left.{ }^{14} \mathrm{C}\right]-\mathrm{p}$-Cymene<smiles>CC(=O)c1ccccc1</smiles>

[ring- $\left.{ }^{14} \mathrm{C}\right]$-Acetophenone<smiles>CC(C)=CCCC(C)=CCO</smiles>

(trans)-[1-14 $\mathrm{C}]-$ Geraniol

Figure 1. Chemical structures of the used model compounds. Radiolabelled $\mathrm{C}$ is marked with an asterisk.

\subsection{Atmospheric BVOC concentrations}

A snapshot of the atmospheric concentration of a range of BVOCs was determined on the day of soil sampling in each of the two forest sites and in the Arctic sampling area. Triplicate $6 \mathrm{~L}$ air samples $(12 \mathrm{~L}$ at the Arctic sites) were drawn through a sorbent cartridge $10 \mathrm{~cm}$ above soil surface (conif- erous, beech and bare Arctic sites) or $5 \mathrm{~cm}$ above the canopy (Arctic heath site). Two types of sorbent cartridges were used in order to capture a range of BVOCs (Tenax TA/Carbograph 1TD as sorbent) and (Carbotrap B/Carboxen 1000/Carboxen 1003) halogenated VOCs, including the model compound chloroform. The sorbent cartridges were sampled and analysed by GC-MS as previously described (Kramshøj et al., 2015; Johnsen et al., 2016). Briefly, VOCs in general were analysed on an Agilent 7890A GC coupled with a 5975 inert MSD/DS EI system with chromatographic separation on a HP-5 capillary column. Halogenated VOCs were analysed on a Shimadzu GC2010 splitting the sample equally to an ECD and a GC2010 Plus MS detector with chromatographic separation on a VOCOL capillary column.

\subsection{Incubations for BVOC mineralization}

Six ${ }^{14}$ C-labelled BVOCs were used as model compounds representing different molecular weights and chemical classes (Fig. 1, Table 1). ${ }^{14} \mathrm{C}$-methanol $\left(58 \mathrm{mCi}\right.$ millimole $\left.{ }^{-1}\right)$, [ring- ${ }^{14} \mathrm{C}-$-]-benzaldehyde $(>99 \%$ radiochemical purity; $60 \mathrm{mCi}^{\text {millimole }}{ }^{-1}$ ) (trans)-[1-14C]Geraniol (99\% radiochemical purity; $55 \mathrm{mCi}$ millimole ${ }^{-1}$ ), [ring- ${ }^{14} \mathrm{C}$-]-acetophenone $(99 \%$ radiochemical purity; $55 \mathrm{mCi}$ millimole ${ }^{-1}$ ) and ${ }^{14} \mathrm{C}$-chloroform (>99\% radiochemical purity; $2.25 \mathrm{mCi}$ millimole ${ }^{-1}$ ) were purchased from American Radiolabeled Chemicals Inc. (St. Louis, MO). [1-methyl- $\left.{ }^{14} \mathrm{C}\right]-p$-cymene $(96 \%$ radiochemical purity; $57 \mathrm{mCi}$ millimole ${ }^{-1}$ ) was purchased from Moravek (Brea, Ca). Stock solutions $\left(3 \times 10^{7} \mathrm{DPM} \mathrm{mL}^{-1}\right)$ were made in sterile water (methanol and benzaldehyde), ethanol (acetophenone, geraniol and $p$-cymene) or acetonitrile (chloroform) and stored at $-18^{\circ} \mathrm{C}$ until use.

Incubations were carried out in $120 \mathrm{~mL}$ serum flasks. Into each flask, 5 (coniferous), 6 (beech and Arctic heath) or 10 (bare Arctic) g of fresh weight (f.w.) soil with natural 


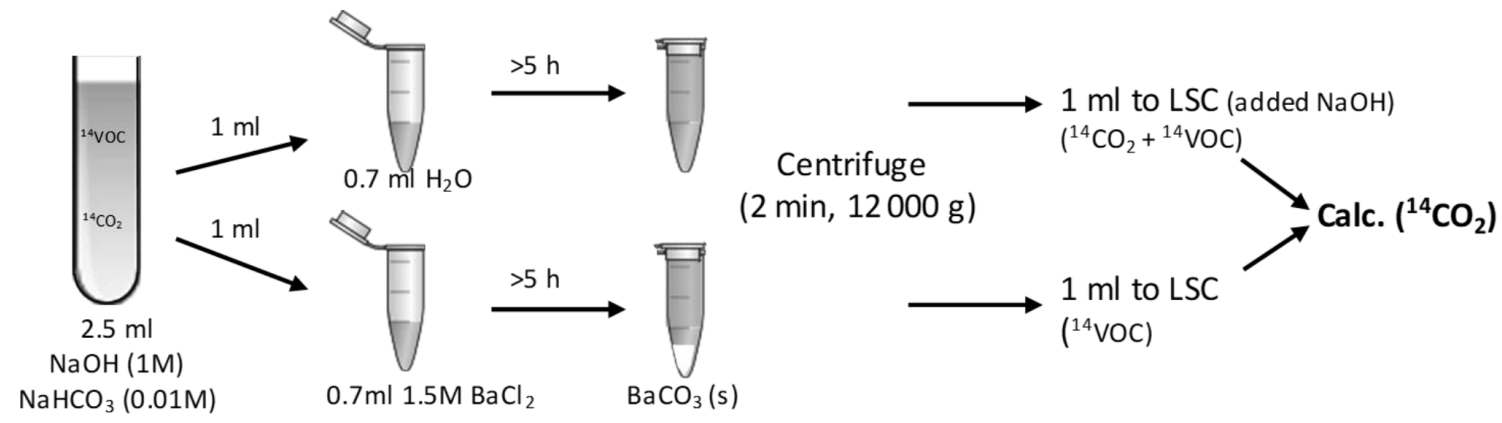

Figure 2. Sketch of the method for capturing ${ }^{14} \mathrm{CO}_{2}$, separating it from dissolved ${ }^{14} \mathrm{C}-\mathrm{BVOC}$ and analysing it by liquid scintillation counting (LSC).

moisture was weighed and equilibrated overnight at $10^{\circ} \mathrm{C}$. A small glass vial containing $2.5 \mathrm{~mL} 1 \mathrm{M} \mathrm{NaOH}$ and $0.01 \mathrm{M}$ $\mathrm{NaHCO}_{3}$ was placed in the flask to trap ${ }^{14} \mathrm{CO}_{2}$ liberated from ${ }^{14} \mathrm{C}$-BVOC mineralization. The $\mathrm{NaHCO}_{3}$ was used in order to precipitate all trapped ${ }^{14} \mathrm{CO}_{2}$ with $\mathrm{Ba}^{2+}$ added during the following analysis procedure. The $0.5 \mathrm{~mL}$ radiolabelled BVOCs dissolved in sterile water were then distributed across the soil with a pipette. The transfer of the BVOCs had to be carried out fast in order not to lose them from the aqueous solution. For each BVOC, portions of the aqueous solution were transferred to scintillation vials containing HiSafe 3 liquid scintillation cocktail (Perkin Elmer, Waltham, MA) just before being transferred to the first incubation flask and just after being transferred to the last incubation flask to ensure that all flasks had received similar ${ }^{14} \mathrm{C}-\mathrm{BVOC}$ concentrations. The scintillation vials were then counted on a liquid scintillation counter (Tri-Carb 2810 TR, PerkinElmer, Waltham, MA) for $30 \mathrm{~min}$ or until $1 \%$ uncertainty (2S, 95\% CL) was achieved. The BVOC concentrations used for incubation corresponded to 43-73 ppbv (64-504 $\mathrm{ng} \mathrm{L}^{-1}$ ), assuming all BVOCs were present in the headspace of the flasks. Most of the BVOCs were, however, likely dissolved in water or adsorbed to the soil, so recalculating to a soil basis $\left(0.8-11 \mu \mathrm{g} \mathrm{kg}^{-1} \mathrm{f}\right.$.w. soil) may be more appropriate.

Immediately after the transfer of the BVOC solution, flasks were closed with crimp-caps containing an aluminacoated septum (Mikrolab Aarhus, Denmark) and incubated at $10^{\circ} \mathrm{C}$ in the dark. At several time points, the alkaline $\mathrm{CO}_{2}$ trap was exchanged through a needle syringe permanently installed in the septum (to avoid loosing BVOCs when exchanging the $\mathrm{CO}_{2}$-trap). $1 \mathrm{~mL}$ was transferred to each of two $2 \mathrm{~mL}$ Eppendorf tubes with either $0.7 \mathrm{~mL}$ water or $0.7 \mathrm{~mL}$ $\mathrm{BaCl}_{2}\left(1.5 \mathrm{M}\right.$, to precipitate trapped ${ }^{14} \mathrm{CO}_{2}$ as $\left.\mathrm{Ba}^{14} \mathrm{CO}_{3}\right)$ to differentiate between trapped ${ }^{14} \mathrm{CO}_{2}$ and dissolved ${ }^{14} \mathrm{C}$ BVOC (Fig. 2). After $5 \mathrm{~h}$ reaction time, the tubes were centrifuged $(12000 \mathrm{~g}, 2 \mathrm{~min})$ and $1 \mathrm{~mL}$ from each tube was counted by liquid scintillation. $1 \mathrm{~mL} 1 \mathrm{M} \mathrm{NaOH}$ had been added to the scintillation liquid for the tube added only wa- ter. This was done to increase the $\mathrm{pH}$ of the liquid and thereby avoid losses of ${ }^{14} \mathrm{CO}_{2}$.

After the last sampling point, $30 \mathrm{~mL}$ methanol was added to the soil in each flask through the permanently installed needle to extract any residual ${ }^{14} \mathrm{C}$-BVOC. After $24 \mathrm{~h}$ of shaking the supernatant was transferred to a $50 \mathrm{~mL}$ centrifuge tube and centrifuged (4000 g, $5 \mathrm{~min}$ ). The ${ }^{14} \mathrm{C}$ activity was then determined in $3 \mathrm{~mL}$ supernatant by liquid scintillation counting.

Incubations were made in three replicates. In addition to each BVOC-soil combination, a negative control was included in which the soil had been sterilized by being autoclaved twice. Oxygen consumption during incubation was determined for each soil type by incubating an additional flask in which oxygen spot sensors had been installed (PreSens, Regensburg, Germany), which were readable through the glass of the bottles.

The incubation method is a modification of previous methods for measuring the mineralization of organic compounds. Suitability and limitations of the method are discussed in the supplementary information.

\subsection{Statistical analyses}

We tested for significant differences between the mineralization curves using Repeated Measures Analysis of Variance in IBM SPSS Statistics 24. The model included incubation time as a within-subject factor and soil type as a betweensubject factor. Different soil types were compared to each other using Tukey's HSD (honestly significant difference) post hoc test. Differences were considered significantly different when $P<0.05$.

\section{Results and discussion}

\subsection{Soil characterization}

The four topsoils used in the study showed clear differences with regards to major soil parameters like soil organic matter content, $\mathrm{pH}$ and microbial biomass (Table 2). The two for- 
Table 2. Soil parameters determined from homogenized samples with major roots removed. Average of three replicate extractions and analyses for 16s and ITS2 $( \pm$ SD) and one for the other parameters. Sample depth corresponds roughly to the depth of the organic layer after removing litter from the top and is the average depth of 10 pooled soil cores. At the bare Arctic soil no organic layer was present. 16s is a measure of bacteria in the soil. ITS2 is a measure of fungal biomass. $\mathrm{O}_{2}$ consumption is measured during mineralization experiments and may be different from that in nature. All parameters except moisture are on a dry-weight basis.

\begin{tabular}{|c|c|c|c|c|c|c|c|}
\hline Soil & $\begin{array}{r}\text { Depth } \\
(\mathrm{cm})\end{array}$ & $\begin{array}{r}\text { SOM } \\
(\%)\end{array}$ & $\mathrm{pH}_{\mathrm{H}_{2} \mathrm{O}}$ & $\begin{array}{r}\text { Moisture } \\
(\text { wt \%) }\end{array}$ & $\begin{array}{l}\text { 16s (gene } \\
\text { copies } g^{-1} \text { ) }\end{array}$ & $\begin{array}{l}\text { ITS2 (gene } \\
\left.\text { copies g }{ }^{-1}\right)\end{array}$ & $\begin{array}{l}\mathrm{O}_{2} \text { consumption } \\
\quad\left(\mu \mathrm{Mg}^{-1} \mathrm{~d}^{-1}\right)\end{array}$ \\
\hline Temperate coniferous & $0-6$ & 78 & 3.8 & 45 & $6.2 \times 10^{10} \pm 2.8 \times 10^{10}$ & $5.5 \times 10^{8} \pm 6.9 \times 10^{7}$ & 9 \\
\hline Arctic heath & $0-6$ & 36 & 5.3 & 51 & $2.8 \times 10^{10} \pm 4.5 \times 10^{10}$ & $7.0 \times 10^{7} \pm 1.5 \times 10^{6}$ & 14 \\
\hline Bare Arctic & $0-5$ & 3.6 & 7.3 & 8.1 & $2.2 \times 10^{9} \pm 1.1 \times 10^{9}$ & $2.4 \times 10^{6} \pm 6.8 \times 10^{5}$ & 0.3 \\
\hline
\end{tabular}

est topsoils differed in soil organic matter content but were both acidic ( $\mathrm{pH}$ just below 4). The Arctic heath topsoil had an organic matter content in between the two forest soils but a higher $\mathrm{pH}$ of 5.3. As expected, the bare Arctic soil differed most, as it comprised the parent mineral soil, while the others were dominated by organic matter accumulation on top of the parent soil. Nevertheless, the bare soil contained $3.6 \%$ soil organic matter and some bacterial biomass (Table 2), which may be due to its close proximity (metre-scale) to vegetated areas. However, despite its relatively high content of organic matter and bacteria, it showed very low oxygen consumption during incubation $\left(0.3 \mu \mathrm{Mg}^{-1}\right.$ dry weight (d.w.) $\left.\mathrm{d}^{-1}\right)$ compared to the three organic soils $\left(5-14 \mu \mathrm{Mg}^{-1}\right.$ d.w. $\left.\mathrm{d}^{-1}\right)$. This indicates that the soil organic matter is not very reactive and/or that the bacterial activity per cell is low in this soil. It should be stressed that the measured oxygen consumption is not necessarily the same as it would be in nature, as the soil was disturbed (homogenized by hand), which may increase the bioavailability of soil organic matter. Fungal biomass (determined as ITS2 gene copies) was much higher in the coniferous soil compared to the other organic soil types, which may be expected as fungi are known to play a key role in the degradation of needle litter (Boberg, 2009).

\subsection{BVOC mineralization}

As model compounds, we chose six BVOCs that have welldescribed natural sources, are commonly detected in nature and have quite different molecular weights and physical and chemical properties (Table 1).

Five of the six BVOCs were rapidly mineralized in all four soils included in the mineralization experiment, with chloroform showing somewhat slower mineralization (Fig. 3). None of the sterilized soil samples showed any detectable mineralization, so the degradation of the BVOCs was in all cases microbially derived. However, great differences were observed with regards to the speed of mineralization, extent of mineralization and variation between soil types. Methanol and benzaldehyde showed the highest mineralization rates. In particular, for methanol (Fig. 3b), mineralization was so fast that the $\mathrm{CO}_{2}$ transfer rate from soil to trap most likely deter- mined the shape of the mineralization curve rather than the speed of mineralization. For example, the theoretical initial (0-2h) mineralization rate in the Arctic heath soil that can be determined with the applied method would be $40 \% \mathrm{~h}^{-1}$ as calculated from the curve in Supplementary Fig. S2, and the observed mineralization of methanol in that soil type was $39 \% \mathrm{~h}^{-1}$ (Table 3). The fact that methanol is degraded quickly in soil is not a surprise, as many isolated soil bacteria have the capability to degrade this BVOC (Kolb, 2009), and different temperate grassland and forest soils have been found to contain at least $10^{6}$ bacteria with the capability to degrade methanol per gram of soil (Stacheter et al., 2013). However, our data are the first to demonstrate degradation of methanol within the range of observed atmospheric concentrations (less than $100 \mathrm{ng} \mathrm{L}^{-1}$; Seco et al., 2007). Degradation of benzaldehyde in soil or by soil microorganisms has not been demonstrated, but benzaldehyde mineralization by pure microbial cultures has been shown (Kamada et al., 2002). Also, benzaldehyde mineralization was so fast in the four soils that the $\mathrm{CO}_{2}$ transfer rate probably influenced the shape of the mineralization curves (Figs. 3d and S2).

Following methanol and benzaldehyde, geraniol and acetophenone had the highest mineralization rates, with most of the mineralization occurring within the first $24 \mathrm{~h}$ of incubation (Fig. 3e, f). What these four rapidly degraded compounds had in common was that differences in mineralization rates between the soil types were minor (Table 3 ) but in many cases still had statistically significant differences in mineralization curves (Fig. 3). For methanol and partly for benzaldehyde the minor differences could be influenced by method limitations (mineralization that was too fast to be kept in pace by transferring $\mathrm{CO}_{2}$ to the trap may have masked any differences). However, for geraniol and acetophenone this was not the case. In other words, Arctic soils mineralized these compounds as quickly as temperate forest soils and perhaps even more interestingly, the bare Arctic soil showed similar mineralization rates to the organic soil types. This is despite a much lower abundance of microorganisms, as determined by qPCR, and a much lower microbial heterotrophic activity during incubation as determined by oxygen consumption 
Table 3. Mineralization parameters calculated from the mineralization experiment shown in Fig. 3. Initial mineralization rate is calculated as the average rate during the first $2 \mathrm{~h}$ of incubation. A lag phase is noted where the initial mineralization rate is not the highest. (Yes) denotes a very weak lag phase.

\begin{tabular}{lrrrr|llll}
\hline & \multicolumn{3}{c}{ Initial mineralization rate $\left(\% \mathrm{~h}^{-1}\right)$} & \multicolumn{5}{c}{ Lag phase? } \\
\cline { 2 - 9 } & Coniferous & Beech & Heath & Bare & Coniferous & Beech & Heath & Bare \\
\hline Chloroform & 0.20 & 0.17 & 0.34 & 0.48 & No & No & No & No \\
Methanol & 38 & 35 & 39 & 25 & No & No & No & No \\
$p$-cymene & 10 & 0.4 & 2.0 & 0.2 & No & Yes & (Yes) & Yes \\
Benzaldehyde & 14 & 13 & 16 & 12 & No & No & No & No \\
Acetophenone & 2.0 & 2.6 & 4.3 & 2.3 & (Yes) & (Yes) & No & (Yes) \\
Geraniol & 1.5 & 3.5 & 4.3 & 2.3 & (Yes) & No & No & No \\
\hline
\end{tabular}

Table 4. Atmospheric concentrations of relevant BVOCs (mean \pm standard deviation, $n=3$ ) measured $10 \mathrm{~cm}$ above the soil surface (coniferous, beech and bare Arctic sites) or $5 \mathrm{~cm}$ above the canopy (Arctic heath site) the day of soil sampling. Methanol could not be analysed with the applied methods. Comparable literature data are included when available.

\begin{tabular}{lcrrr}
\hline & \multicolumn{3}{c}{ Atmospheric concentration $\left(\mathrm{ng} \mathrm{L}{ }^{-1}\right)$} & $\begin{array}{c}\text { Initial headspace concentration } \\
\text { during incubation }\left(\mathrm{ng} \mathrm{L}^{-1}\right)^{3}\end{array}$ \\
\cline { 2 - 4 } Name & \multicolumn{1}{c}{ Coniferous ${ }^{1}$} & Beech & Arctic $^{2}$ & \\
\hline Oxygenated monoterpenes & $0.00^{\mathrm{e}} \pm 0.00$ & $0.00 \pm 0.00$ & $0.01 \pm 0.01$ & 504 \\
Hydrocarbon monoterpenes & & & \\
Benzaldehyde & $3.36^{\mathrm{a}, \mathrm{f}} \pm 0.32$ & $0.37^{\mathrm{b}} \pm 0.12$ & $0.71^{\mathrm{c}} \pm 0.10$ & 260 \\
Acetophenone & $1.01 \pm 0.03$ & $1.14 \pm 0.08$ & $0.00 \pm 0.00$ & 286 \\
Chloroform & $0.44 \pm 0.06$ & $0.59 \pm 0.03$ & $0.01 \pm 0.01$ & 350 \\
Methanol (literature data) & $0.10^{\mathrm{g}} \pm 0.02$ & $0.06 \pm 0.00$ & $0.06 \pm 0.00$ & 340 \\
\hline
\end{tabular}

${ }^{1} n=2$ due to loss of a sample, except for chloroform $(n=3) .{ }^{2}$ One sample from the bare soil, two from the Arctic heath. ${ }^{3}$ Assuming all added BVOC is present in headspace, although most will likely be adsorbed to soil or dissolved in water. ${ }^{\text {a }}$ Mainly pinenes, camphene, carene and $p$-cymene. ${ }^{\mathrm{b}}$ Mainly camphene, $\alpha$-pinene, $\delta$-terpinene and carene. ${ }^{\mathrm{c}}$ Mainly $\delta$-terpinene. ${ }^{\mathrm{d}}$ Comparable literature values but from a different ecosystem type are from 0.5 to $50 \mathrm{ng} \mathrm{L}^{-1}$ (Barney et al., 2009). ${ }^{\mathrm{e}}$ Air samples taken at the interface between litter and atmosphere have shown concentrations of 60-390 ng L ${ }^{-1}$ (Ketola et al., 2011). ${ }^{\mathrm{f}}$ Air samples taken at the interface between litter and atmosphere have shown concentrations of $10-24300 \mathrm{ng} \mathrm{L}^{-1}$ (Ketola et al., 2011). ${ }^{\mathrm{g}}$ Comparable literature data are from 0.08 to $2.1 \mathrm{ng} \mathrm{L}^{-1}$ (Albers et al., 2010).

(Table 2). Geraniol mineralization has previously been investigated in soil sampled underneath Populus tremula tree crowns (Owen et al., 2007). The mineralization observed in that study was different from the one we observed, with an initial lag phase and less than $5 \%$ mineralization in the first $\sim 10 \mathrm{~h}$. The lag phase was followed by maximum mineralization rates of $1-3 \% \mathrm{~h}^{-1}$, which is close to what we observed right after the start of the incubation (Table 3). An extremely high geraniol concentration of $600 \mathrm{mg} \mathrm{kg}^{-1}$ soil was used in that study compared to $6-11 \mu \mathrm{g} \mathrm{kg}^{-1}$ soil in ours, which is the most likely cause of this difference in mineralization. The geraniol concentration used by Owen et al. (2007) would allow growth with geraniol as substrate (hence the lag phase), while the concentrations we used would allow only very limited microbial growth. However, the two studies all in all demonstrate that oxygenated monoterpenes may be degraded within a very large concentration range in soil.

$p$-cymene was the only BVOC that showed clear differences in mineralization between the soil types (Fig. 3c). Initial mineralization rates were by far the highest in the coniferous forest soil $\left(10 \% \mathrm{~h}^{-1}\right.$, Table 3$)$ followed by the Arctic heath soil $\left(2 \% \mathrm{~h}^{-1}\right)$, the beech forest soil $\left(0.4 \% \mathrm{~h}^{-1}\right)$ and the bare Arctic soil $\left(0.2 \% \mathrm{~h}^{-1}\right)$. In other words, the coniferous forest soil showed an initial mineralization rate that was 25 times higher compared to the beech forest soil sampled just $750 \mathrm{~m}$ away. In addition, the three soils with the slowest mineralizations showed a slightly s-shaped mineralization curve, meaning that the mineralization rate increased after an initial lag phase with slower mineralization (Fig. 3c and Table 3). All in all it appears that the coniferous forest soil is especially adapted to degrade $p$-cymene. $p$-cymene is a hydrocarbon monoterpene (monoterpene without heteroatoms) and these are emitted in very high concentrations in coniferous forests (Guenther et al., 1994; Rinne et al., 2009). Our measurements also showed a much higher concentration of this BVOC group in the atmosphere of the coniferous forest compared to the other sampling sites (Table 4). In addition, needle litter emits high amounts of hydrocarbon monoterpenes (Aaltonen et al., 2011; Faiola et al., 2014), exposing the soil to these compounds. Hydrocarbon monoterpenes are also found in higher concentrations in soil under conifers than deciduous trees (Smolander et al., 2006). All in all it 

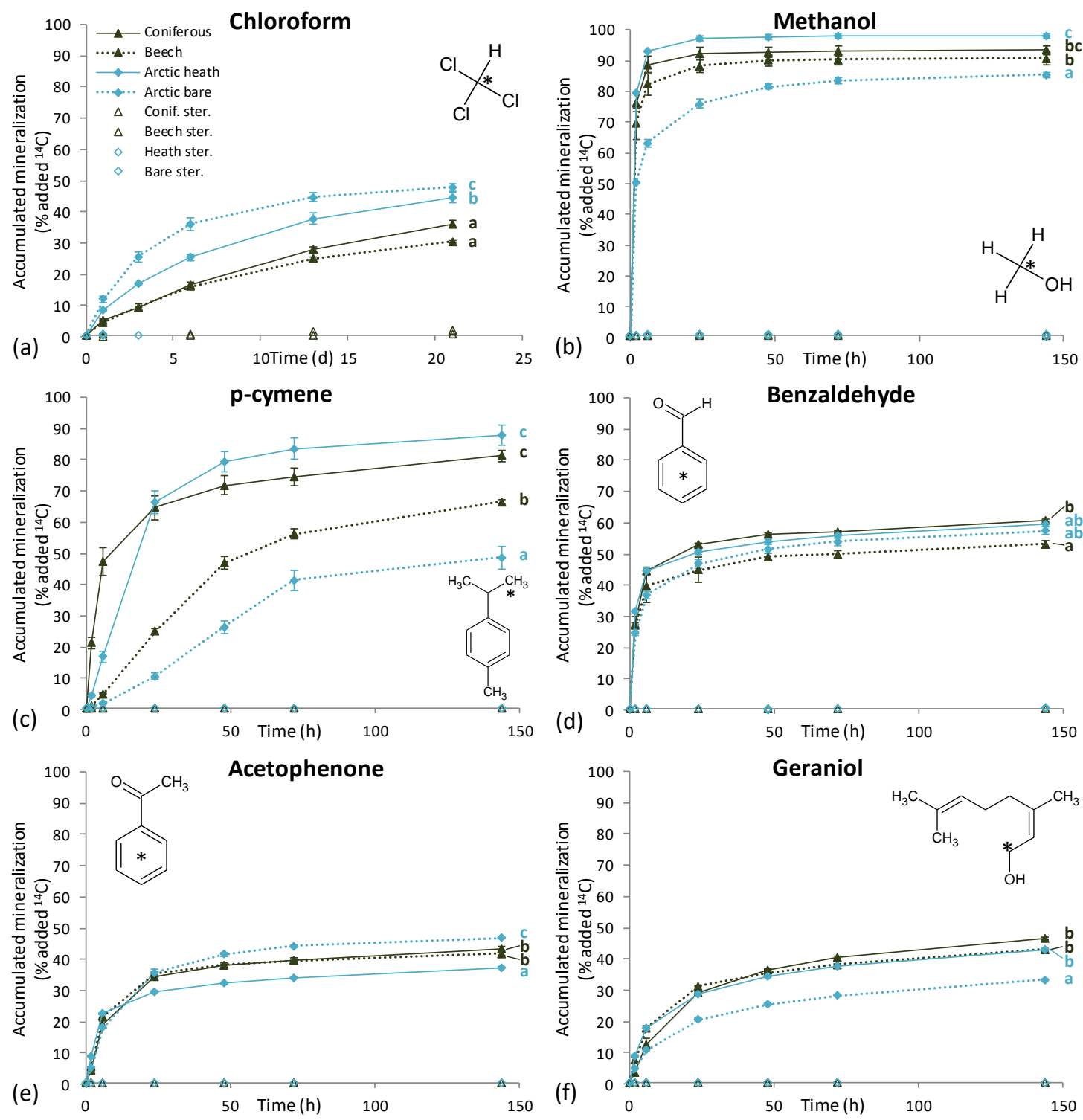

Figure 3. Mineralization curves for six BVOCs in soil from coniferous forest, beech forest, Arctic heath and bare Arctic soil. Initial BVOC concentrations varied from 0.8 to $11 \mu \mathrm{g} \mathrm{kg} \mathrm{soil}{ }^{-1}$. "Ster." means that soil was sterilized twice by autoclaving. Error bars are standard deviation of triplicate incubations. Some error bars are smaller than the symbols. Letters to the right of the mineralization curves denote results of Tukey's post hoc test after Repeated Measures Analysis of Variance. Curves sharing a letter are not significantly different from each other $(P>0.05)$. Note the incubation time unit for chloroform is days and for the other BVOCs it is hours.

seems likely that the high adaptation for $p$-cymene mineralization in the coniferous forest soil is caused by a high natural input of hydrocarbon monoterpenes to this soil type.

Chloroform, which is a well-known pollutant but also a natural product in soil (Hoekstra et al., 1998; Albers et al., 2010; Johnsen et al., 2016), was mineralized in all four soils (Fig. 3a) but at much slower rates compared to the other BVOCs (Table 3). Interestingly, the Arctic soils showed a faster mineralization of chloroform than the temperate forest soils with the bare Arctic soil being the fastest. This indicates that chloroform mineralization in soil does not adapt to the natural exposure, since much higher chloroform formation, emission and soil air concentrations are found in coniferous forests compared to Arctic heaths (Albers et al., 2011, 2017; Johnsen et al., 2016). Chloroform mineralization was previously determined at $10{ }^{\circ} \mathrm{C}$ in a spruce forest soil in which initial mineralization rates of $0.01-0.04 \% \mathrm{~h}^{-1}$ were observed (Albers et al., 2011). These rates are roughly 10 times lower than the ones observed in our study $\left(0.2-0.5 \% \mathrm{~h}^{-1}\right.$, Table 3$)$. The spruce forest soil was similar to the coniferous forest soil 
used in our study, but there was a difference in chloroform concentration, which in our case was $4-7 \mu \mathrm{g} \mathrm{kg}^{-1}$ soil and in the previous study was $350 \mu \mathrm{g} \mathrm{kg}^{-1}$ soil. This stresses that the concentration used during incubation may determine to a high degree how fast the compound is mineralized. On the other hand, if mineralization rates are recalculated to mass unit per time unit, differences in the case of chloroform mineralization would be much smaller between the two studies.

The extent of mineralization (determined as ${ }^{14} \mathrm{CO}_{2}$ release at the termination of experiment) was in general similar between soils but differed greatly between the BVOCs (Fig. 3 and Table S1). Methanol showed an almost $100 \%{ }^{14} \mathrm{CO}_{2}$ release, while acetophenone and geraniol released only $40 \%$. The $40 \%$ release should not be interpreted as if only $40 \%$ of the compound was degraded but rather as if $60 \%$ of the mineralized compound was used as a carbon source for microbial growth. This is a generally accepted interpretation of mineralization curves that often go to yields of only 40 $50 \%$ with the remaining part incorporated into biomass that is only slowly mineralized along with microbial turnover (Nowak et al., 2011; Glanville et al., 2016). Just after incubation, we extracted non-degraded or metabolized BVOCs with methanol, and only sterilized samples released a major pool of methanol-extractable ${ }^{14} \mathrm{C}$ (typically between 50 and $95 \%$ ), while non-sterilized samples typically released less than $5 \%$ (Table S1). This strongly supports the interpretation that all BVOC was degraded. Geraniol was an exception to this, with $15-25 \%$ of added ${ }^{14} \mathrm{C}$ extracted in non-sterilized samples and $83-92 \%$ extracted in sterilized samples. While methanol, benzaldehyde, acetophenone and $p$-cymene were conclusively degraded completely within $140 \mathrm{~h}$ (and presumably much faster), we therefore cannot exclude the possibility that some less degradable products of geraniol have accumulated. It has been shown that some fungi have the ability to metabolize geraniol into various derivatives (Demyttenaere et al., 2000).

Based on the extent of mineralization, some compounds (e.g. methanol) were used only as a source of energy (as electron donor), while others (e.g. geraniol and acetophenone) were also used as a carbon source for growth. Recently, Gunina et al. (2017) suggested that the oxidation state of a $\mathrm{C}$ atom determines how much is released as $\mathrm{CO}_{2}$, and how much is incorporated into biomass. They found a positive relationship between carbon oxidation state and ${ }^{14} \mathrm{CO}_{2}$ release for seven easily degradable low-molecular-weight sugars, acids and amino acids. However, the carbon atom in methanol (oxidation state -2 ) is more reduced than the labelled carbon atoms in geraniol (oxidation state 0 ), benzaldehyde and acetophenone (both -1 ), so the oxidation state does not determine the mineralization extent of the model BVOCs.

$p$-cymene was an exception from the minor difference in mineralization extent between soil types. In soil from the coniferous forest and from the Arctic heath, more than $80 \%$ of the ${ }^{14} \mathrm{C}$ was liberated as ${ }^{14} \mathrm{CO}_{2}$ (Fig. $3 \mathrm{c}$ and Table $\mathrm{S} 1 \mathrm{in}$ the Supplement). In the bare Arctic soil only half of this release was measured, while the beech forest soil was in between. In all soils, $p$-cymene degradation was complete at the end of the experiment, since in all soils we could only extract a very small amount of ${ }^{14} \mathrm{C}$ with methanol (Table S1). One possible explanation for this difference is that different microorganisms degrade $p$-cymene in the studied soils and that these different organisms have different degradation strategies for the compound, i.e. different fractions used for energy and growth. Another perhaps more likely explanation is that $p$-cymene is used as a carbon source mainly when degradation is occurring along with microbial growth. This explanation is supported by the fact that the slower the initial degradation is and the more s-shaped the mineralization curves are (presence of lag phase, Table 3), the more carbon there is that seems to be accumulated into biomass (less ${ }^{14} \mathrm{CO}_{2}$ release, Fig. 3c). This is also supported by the earlierobserved higher mineralization extent of ${ }^{14} \mathrm{C}$-geraniol at high concentrations that supported growth (mineralization extent of $64-75 \%$, Owen et al., 2007) compared to the mineralization extent we observed for this compound with no or very little growth (33-46\%, Fig. 3f and Table S1). In addition, the highest mineralization extent in the case of geraniol was observed in the coniferous forest soil, which was the only soil in which a (weak) lag phase was observed (Table 3).

The potential for very fast mineralization of different BVOCs in different temperate and Arctic soils may have significant environmental implications. A few previous studies have shown deposition of BVOCs onto soil (Ramirez et al., 2010; Spielmann et al., 2017) or a bidirectional atmospheresoil exchange of certain BVOCs (Asensio et al., 2007, 2008; Gray et al., 2014), but the mechanism behind the uptake of BVOCs into or onto soil has been largely uninvestigated. Our results suggest that BVOCs will be taken up from the atmosphere by microorganisms that then mineralize the compounds. The concentration of BVOCs in the atmosphere is very low, also at the sites at which we sampled soil (Table 4). Mineralization experiments cannot be carried out at such low concentrations, but we used BVOC concentrations that are much more realistic than those used in previous degradation studies. Furthermore, similar atmospheric concentrations to those used for incubations have been observed in nature for methanol (Seco et al., 2007), chloroform (Albers et al., 2011) and monoterpenes (Barney et al., 2009).

It is therefore very likely that soil microorganisms also take up and mineralize BVOCs in the natural environment and most likely also in urban environments, where concentrations in the air can be much higher due to additional anthropogenic input (Seco et al., 2007). In situ uptake studies using, for example, proton-transfer-reaction mass spectrometry should be carried out in order to provide quantitative estimates of the importance of BVOC uptake in soil. However, simultaneous formation and degradation of the compounds is a complicating aspect in such studies. The use of labelled compounds in the field to determine simultaneous formation and degradation, as previously done in laboratory stud- 
ies with methane (von Fischer and Hedin, 2002) and methyl halides (Rhew et al., 2003), could be a great supplement to more conventional PTR-MS studies.

In addition to the uptake from the atmosphere, the very fast mineralization rates are likely important in shaping the net BVOC emissions from soil. The net BVOC release from the soil to the atmosphere is in general low compared to the plant emissions (Peñuelas et al., 2014), but emissions may represent a minor portion of the amount that was excreted by soil microbes (Insam and Seewald, 2010; Garbeva et al., 2014) or by roots (Lin et al., 2007; Delory et al., 2016), produced, for example, with the purpose of communication (Garbeva et al., 2014; Delory et al., 2016). It is thus possible that BVOCs are a significant source of carbon to soil microbes and hence that BVOC formation and degradation may be important but little-recognized parts of the internal carbon cycle in soil. In addition, plant litter releases BVOCs from both abiotic and biotic processes (for example terpenoids, Faiola et al., 2013 and methanol, Gray et al., 2010). These BVOCs may never reach the atmosphere but are rather an input of degradable carbon to microorganisms in the topsoil.

\section{Conclusions}

We have shown that six chemically very different BVOCs can all be mineralized by microbes in Arctic and temperate soils at environmentally relevant concentrations. Five of the BVOCs were mineralized very quickly, but still we observed a relatively large compound-to-compound variation in mineralization rate as well as mineralization extent compared to a much lower soil-to-soil variation. $p$-cymene was an exception to this pattern, with large differences in both mineralization rate and extent between soils of different origin. It is thus clear that soil microbes are able to completely and quickly degrade BVOCs released by above-ground vegetation, soil microbes and plant roots. In addition, BVOC formation and degradation may furthermore be important but little-recognized parts of internal carbon cycling in soil. Additional studies should be carried out to quantify these processes in nature.

Data availability. The data set related to Fig. 3 has been provided as a Supplement.

Supplement. The supplement related to this article is available online at: https://doi.org/10.5194/bg-15-3591-2018-supplement.

Competing interests. The authors declare that they have no conflict of interest.
Acknowledgements. We wish to thank Pia Bach Jacobsen, GEUS, for excellent technical assistance in the laboratory. We also thank Anders Priemé, Copenhagen University for advice on the qPCR targeting the fungal community and for providing the ITS2 standard. The study was financially supported by the Danish Council for Independent Research Natural Sciences (DFF-4002-00495 and DFF-4181-00141), the European Research Council (ERC) under the European Union's Horizon 2020 research and innovation programme (grant agreement no. 771012) and by the Danish National Research Foundation (CENPERM DNRF100).

Edited by: Ivonne Trebs

Reviewed by: Mari Mäki and one anonymous referee

\section{References}

Aaltonen, H., Pumpanen, J., Pihlatie, M., Hakola, H., Hellén, H., Kulmala, L., Vesala, T., and Bäck, J.: Boreal pine forest floor biogenic volatile organic compound emissions peak in early summer and autumn, Agr. Forest Meteorol., 151, 682-691, https://doi.org/10.1016/J.AGRFORMET.2010.12.010, 2011.

Albers, C. N., Laier, T., and Jacobsen, O. S.: Formation, fate and leaching of chloroform in coniferous forest soils, Appl. Geochem., 25, 1525-1535, https://doi.org/10.1016/j.apgeochem.2010.08.003, 2010.

Albers, C. N., Jacobsen, O. S., Flores, É. M. M., Pereira, J. S. F., and Laier, T.: Spatial variation in natural formation of chloroform in the soils of four coniferous forests, Biogeochemistry, 103, 317 334, https://doi.org/10.1007/s10533-010-9467-9, 2011.

Albers, C. N., Jacobsen, O. S., Flores, E. M. M., and Johnsen, A. R.: Arctic and Subarctic Natural Soils Emit Chloroform and Brominated Analogues by Alkaline Hydrolysis of Trihaloacetyl Compounds, Environ. Sci. Technol., 51, 6131-6138, https://doi.org/10.1021/acs.est.7b00144, 2017.

Asensio, D., Peñuelas, J., Filella, I., and Llusià, J.: On-line screening of soil VOCs exchange responses to moisture, temperature and root presence, Plant Soil, 291, 249-261, https://doi.org/10.1007/s11104-006-9190-4, 2007.

Asensio, D., Peñuelas, J., Prieto, P., Estiarte, M., Filella, I., and Llusià, J.: Interannual and seasonal changes in the soil exchange rates of monoterpenes and other VOCs in a Mediterranean shrubland, Eur. J. Soil Sci., 59, 878-891, https://doi.org/10.1111/j.1365-2389.2008.01057.x, 2008.

Bäck, J., Aaltonen, H., Hellén, H., Kajos, M. K., Patokoski, J., Taipale, R., Pumpanen, J., and Heinonsalo, J.: Variable emissions of microbial volatile organic compounds (MVOCs) from root-associated fungi isolated from Scots pine, Atmos. Environ., 44, 3651-3659, https://doi.org/10.1016/J.ATMOSENV.2010.06.042, 2010.

Barney, J. N., Sparks, J. P., Greenberg, J., Whitlow, T. H., and Guenther, A.: Biogenic volatile organic compounds from an invasive species: impacts on plant-plant interactions, Plant Ecol., 203, 195-205, https://doi.org/10.1007/s11258-008-9529-4, 2009.

Boberg, J.: Litter decomposing fungi in boreal forests, Dept. of Forest Mycology and Pathology, Swedish University of Agricultural Sciences, 67 pp., 2009. 
Chen, W. and Viljoen, A. M.: Geraniol - A review of a commercially important fragrance material, S. Afr. J. Bot., 76, 643-651, https://doi.org/10.1016/J.SAJB.2010.05.008, 2010.

Christiansen, C. T., Haugwitz, M. S., Priemé, A., Nielsen, C. S., Elberling, B., Michelsen, A., Grogan, P., and Blok, D.: Enhanced summer warming reduces fungal decomposer diversity and litter mass loss more strongly in dry than in wet tundra, Glob. Change Biol., 23, 406-420, https://doi.org/10.1111/gcb.13362, 2017.

Cleveland, C. C. and Yavitt, J. B.: Consumption of atmospheric isoprene in soil, Geophys. Res. Lett., 24, 2379-2382, https://doi.org/10.1029/97GL02451, 1997.

Cripps, R. E.: The microbial metabolism of acetophenone, Metabolism of acetophenone and some chloroacetophenones by an Arthrobacter species, Biochem. J., 152, 233-241, 1975.

Delory, B. M., Delaplace, P., Fauconnier, M.-L., and du Jardin, P.: Root-emitted volatile organic compounds: can they mediate belowground plant-plant interactions?, Plant Soil, 402, 1-26, https://doi.org/10.1007/s11104-016-2823-3, 2016.

Demyttenaere, J. C. R., del Carmen Herrera, M., and De Kimpe, N.: Biotransformation of geraniol, nerol and citral by sporulated surface cultures of Aspergillus niger and Penicillium sp., Phytochemistry, 55, 363-373, https://doi.org/10.1016/S00319422(00)00330-7, 2000.

El Khawand, M., Crombie, A. T., Johnston, A., Vavlline, D. V., McAuliffe, J. C., Latone, J. A., Primak, Y. A., Lee, S.-K., Whited, G. M., McGenity, T. J., and Murrell, J. C.: Isolation of isoprene degrading bacteria from soils, development of isoA gene probes and identification of the active isoprene-degrading soil community using DNA-stable isotope probing, Environ. Microbiol., 18, 2743-2753, https://doi.org/10.1111/1462-2920.13345, 2016.

Faiola, C. L., VanderSchelden, G. S., Wen, M., Elloy, F. C., Cobos, D. R., Watts, R. J., Jobson, B. T., and VanReken, T. M.: SOA Formation Potential of Emissions from Soil and Leaf Litter, Environ. Sci. Technol., 48, 938-946, https://doi.org/10.1021/es4040045, 2014.

Feld, L., Nielsen, T. K., Hansen, L. H., Aamand, J., and Albers, C. N.: Establishment of Bacterial Herbicide Degraders in a Rapid Sand Filter for Bioremediation of PhenoxypropionatePolluted Groundwater, Appl. Environ. Microb., 82, 878-887, https://doi.org/10.1128/AEM.02600-15, 2016.

Garbeva, P., Hordijk, C., Gerards, S., and de Boer, W.: Volatile-mediated interactions between phylogenetically different soil bacteria, Front. Microbiol., 5, 289, https://doi.org/10.3389/fmicb.2014.00289, 2014.

Glanville, H. C., Hill, P. W., Schnepf, A., Oburger, E., and Jones, D. L.: Combined use of empirical data and mathematical modelling to better estimate the microbial turnover of isotopically labelled carbon substrates in soil, Soil Biol. Biochem., 94, 154168, https://doi.org/10.1016/j.soilbio.2015.11.016, 2016.

Glasius, M. and Goldstein, A. H.: Recent Discoveries and Future Challenges in Atmospheric Organic Chemistry, Environ. Sci. Technol., 50, 2754-2764, https://doi.org/10.1021/acs.est.5b05105, 2016.

Gray, C. M., Monson, R. K., and Fierer, N.: Emissions of volatile organic compounds during the decomposition of plant litter, J. Geophys. Res., 115, G03015, https://doi.org/10.1029/2010JG001291, 2010.

Gray, C. M., Monson, R. K., and Fierer, N.: Biotic and abiotic controls on biogenic volatile organic compound fluxes from a subalpine forest floor, J. Geophys. Res.-Biogeo., 119, 547-556, https://doi.org/10.1002/2013JG002575, 2014.

Gray, C. M., Helmig, D., and Fierer, N.: Bacteria and fungi associated with isoprene consumption in soil, Elem. Sci. Anthr., 3, 000053, https://doi.org/10.12952/journal.elementa.000053, 2015.

Guenther, A., Zimmerman, P., and Wildermuth, M.: Natural volatile organic compound emission rate estimates for US woodland landscapes, Atmos. Environ., 28, 1197-1210, https://doi.org/10.1016/1352-2310(94)90297-6, 1994.

Gunina, A., Smith, A. R., Kuzyakov, Y., and Jones, D. L.: Microbial uptake and utilization of low molecular weight organic substrates in soil depend on carbon oxidation state, Biogeochemistry, 133, 89-100, https://doi.org/10.1007/s10533-017-0313-1, 2017.

Gutiérrez-Luna, F. M., López-Bucio, J., Altamirano-Hernández, J., Valencia-Cantero, E., de la Cruz, H. R., and MacíasRodríguez, L.: Plant growth-promoting rhizobacteria modulate root-system architecture in Arabidopsis thaliana through volatile organic compound emission, Symbiosis, 51, 75-83, https://doi.org/10.1007/s13199-010-0066-2, 2010.

Hoekstra, E. J., de Leer, E. W. B., and Brinkman, U. A. T.: Natural Formation of Chloroform and Brominated Trihalomethanes in Soil, Environ. Sci. Technol., 32, 3724-3729, https://doi.org/10.1021/es980127c, 1998.

Insam, H. and Seewald, M. S. A.: Volatile organic compounds (VOCs) in soils, Biol. Fert. Soils, 46, 199-213, https://doi.org/10.1007/s00374-010-0442-3, 2010.

Jardine, K., Abrell, L., Kurc, S. A., Huxman, T., Ortega, J., and Guenther, A.: Volatile organic compound emissions from Larrea tridentata (creosotebush), Atmos. Chem. Phys., 10, 1219112206, https://doi.org/10.5194/acp-10-12191-2010, 2010.

Johnsen, A. R., Jacobsen, O. S., Gudmundsson, L., and Albers, C. N.: Chloroform emissions from arctic and subarctic ecosystems in Greenland and Northern Scandinavia, Biogeochemistry, 130 53-65, https://doi.org/10.1007/s10533-016-0241-5, 2016.

Kamada, F., Abe, S., Hiratsuka, N., Wariishi, H., and Tanaka, H.: Mineralization of aromatic compounds by brownrot basidiomycetes - mechanisms involved in initial attack on the aromatic ring, Microbiology, 148, 1939-1946, https://doi.org/10.1099/00221287-148-6-1939, 2002.

Kesselmeier, J. and Staudt, M.: Biogenic Volatile Organic Compounds (VOC): An Overview on Emission, Physiology and Ecology, J. Atmos. Chem., 33, 23-88, https://doi.org/10.1023/A:1006127516791, 1999.

Ketola, R. A., Kiuru, J. T., Kotiaho, T., Kitunen, V., and Smolander, A.: Feasibility of membrane inlet mass spectrometry for on-site screening of volatile monoterpenes and monoterpene alcohols in forest soil atmosphere, Boreal Environ. Res., 16, 36-46, 2011.

Kleinheinz, G. T., Bagley, S. T., John, W. P. St., Rughani, J. R., and McGinnis, G. D.: Characterization of Alpha-Pinene-Degrading Microorganisms and Application to a Bench-Scale Biofiltration System for VOC Degradation, Arch. Environ. Cont. Tox., 37, 151-157, https://doi.org/10.1007/s002449900500, 1999.

Kolb, S.: Aerobic methanol-oxidizing Bacteria in soil, FEMS Microbiol. Lett., 300, 1-10, https://doi.org/10.1111/j.15746968.2009.01681.x, 2009.

Kramshøj, M., Vedel-Petersen, I., Schollert, M., Rinnan, Å., Nymand, J., Ro-Poulsen, H., and Rinnan, R.: Large increases in Arctic biogenic volatile emissions are a direct effect of warm- 
ing, Nat. Geosci., 9, 349-352, https://doi.org/10.1038/ngeo2692, 2016.

Laothawornkitkul, J., Taylor, J. E., Paul, N. D., and Hewitt, C. N.: Biogenic volatile organic compounds in the Earth system, New Phytol., 183, 27-51, https://doi.org/10.1111/j.14698137.2009.02859.x, 2009.

Laturnus, F. and Matucha, M.: Chloride - a precursor in the formation of volatile organochlorines by forest plants?, J. Environ. Radioactiv., 99, 119-125, https://doi.org/10.1016/j.jenvrad.2007.07.008, 2008.

Leff, J. W. and Fierer, N.: Volatile organic compound (VOC) emissions from soil and litter samples, Soil Biol. Biochem., 40, 16291636, https://doi.org/10.1016/J.SOILBIO.2008.01.018, 2008.

Lin, C., Owen, S. M., and Peñuelas, J.: Volatile organic compounds in the roots and rhizosphere of Pinus spp., Soil Biol. Biochem., 39, 951-960, https://doi.org/10.1016/J.SOILBIO.2006.11.007, 2007.

McNeal, K. S. and Herbert, B. E.: Volatile Organic Metabolites as Indicators of Soil Microbial Activity and Community Composition Shifts, Soil Sci. Soc. Am. J., 73, 579-588, https://doi.org/10.2136/sssaj2007.0245, 2009.

Misra, G., Pavlostathis, S. G., Perdue, E. M., and Araujo, R.: Aerobic biodegradation of selected monoterpenes, Appl. Microbiol. Biot., 45, 831-838, https://doi.org/10.1007/s002530050770, 1996.

Nowak, K. M., Miltner, A., Gehre, M., Schäffer, A., and Kästner, M.: Formation and Fate of Bound Residues from Microbial Biomass during 2,4-D Degradation in Soil, Environ. Sci. Technol., 45, 999-1006, https://doi.org/10.1021/es103097f, 2011.

Ortega, J., Helmig, D., Daly, R. W., Tanner, D. M., Guenther, A. B., and Herrick, J. D.: Approaches for quantifying reactive and lowvolatility biogenic organic compound emissions by vegetation enclosure techniques - Part B: Applications, Chemosphere, 72, 365-380, https://doi.org/10.1016/j.chemosphere.2008.02.054, 2008.

Owen, S. M., Clark, S., Pompe, M., and Semple, K. T.: Biogenic volatile organic compounds as potential carbon sources for microbial communities in soil from the rhizosphere of Populus tremula, FEMS Microbiol. Lett., 268, 34-39, https://doi.org/10.1111/j.1574-6968.2006.00602.x, 2007.

Peñuelas, J. and Staudt, M.: BVOCs and global change, Trends Plant Sci., 15, 133-144, https://doi.org/10.1016/J.TPLANTS.2009.12.005, 2010.
Peñuelas, J., Asensio, D., Tholl, D., Wenke, K., Rosenkranz, M., Piechulla, B., and Schnitzzler, J. P.: Biogenic volatile emissions from the soil, Plant. Cell Environ., 37, 1866-1891, https://doi.org/10.1111/pce.12340, 2014.

Ramirez, K. S., Lauber, C. L., and Fierer, N.: Microbial consumption and production of volatile organic compounds at the soil-litter interface, Biogeochemistry, 99, 97-107, https://doi.org/10.1007/s10533-009-9393-x, 2010.

Rhew, R. C., Aydin, M., and Saltzman, E. S.: Measuring terrestrial fluxes of methyl chloride and methyl bromide using a stable isotope tracer technique, Geophys. Res. Lett., 30, 2103, https://doi.org/10.1029/2003GL018160, 2003.

Rinne, J., Back, J., and Hakola, H.: Biogenic volatile organic compound emissions from the Eurasian taiga: current knowledge and future directions, Boreal Environ. Res., 14, 807-826, 2009.

Schink, B. and Zeikus, J. G.: Microbial methanol formation: A major end product of pectin metabolism, Curr. Microbiol., 4, 387389, https://doi.org/10.1007/BF02605383, 1980.

Schulz, S. and Dickschat, J. S.: Bacterial volatiles: the smell of small organisms, Nat. Prod. Rep., 24, 814-842, https://doi.org/10.1039/b507392h, 2007.

Seco, R., Peñuelas, J., and Filella, I.: Short-chain oxygenated VOCs: Emission and uptake by plants and atmospheric sources, sinks, and concentrations, Atmos. Environ., 41, 2477-2499, https://doi.org/10.1016/j.atmosenv.2006.11.029, 2007.

Smolander, A., Ketola, R. A., Kotiaho, T., Kanerva, S., Suominen, K., and Kitunen, V.: Volatile monoterpenes in soil atmosphere under birch and conifers: Effects on soil N transformations, Soil Biol. Biochem., 38, 3436-3442, https://doi.org/10.1016/j.soilbio.2006.05.019, 2006.

Spielmann, F. M., Langebner, S., Ghirardo, A., Hansel, A., Schnitzler, J.-P., and Wohlfahrt, G.: Isoprene and $\alpha$-pinene deposition to grassland mesocosms, Plant Soil, 410, 313-322, https://doi.org/10.1007/s11104-016-3009-8, 2017.

Stacheter, A., Noll, M., Lee, C. K., Selzer, M., Glowik, B., Ebertsch, L., Mertel, R., Schulz, D., Lampert, N., Drake, H. L., and Kolb, S.: Methanol oxidation by temperate soils and environmental determinants of associated methylotrophs, ISME J., 7, 1051-1064, https://doi.org/10.1038/ismej.2012.167, 2013.

Von Fischer, J. C. and Hedin, L. O.: Separating methane production and consumption with a field-based isotope pool dilution technique, Global Biogeochem. Cy., 16, 1-13, https://doi.org/10.1029/2001GB001448, 2002. 